\title{
Legal and Ethical Obligations of Oil Companies in Preserving Natural Environment; a Case Study of the Kurdistan Regional Government's Production Sharing Contracts"
}

\author{
Arez Mohammed Sediq Othman \\ Assistant Lecturer at Sulaimani University -College of Law and Politics \\ Law department
}

\begin{abstract}
Apart from having many obligations, oil companies have both legal and ethical obligations to protect natural environment in the country in which they operate. Every country has its own legislation to regulate aspects of oil companies' operations in order not to destroy the natural surroundings of their operation area. Complying with these requirements has mutual interest for both the host country and the company as the latter can improve its reputation by taking steps toward preserving natural environment of the host country. Accordingly, there are many oil companies operating in Kurdistan Region of Iraq that should bear the same responsibilities. However, insufficient environmental legislations and the lack of enforcing the applicable laws have encouraged oil companies not to take necessary measures for both protection and providing remedies for any environmental destruction. The paper argues that the legal obligations to protect environment should be enforced in an appropriate way alongside with corporate social responsibilities toward the host country in terms of preserving natural environment and compensating all kinds of damages that cause natural environment.
\end{abstract}

بوختهى تويُئينهوه

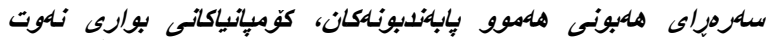

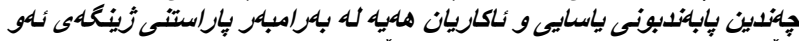

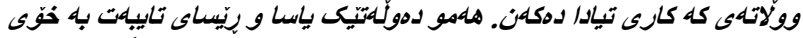

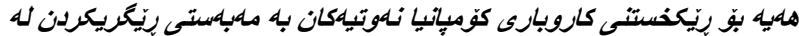

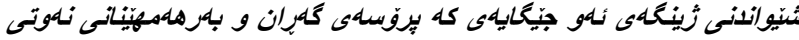

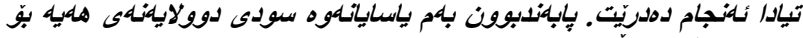

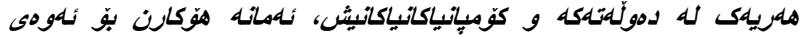

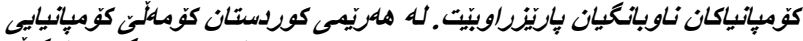

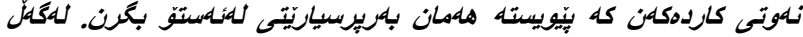

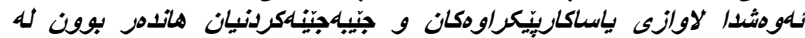

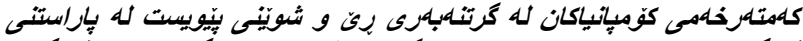

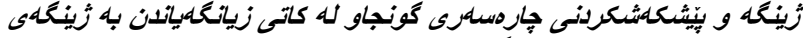

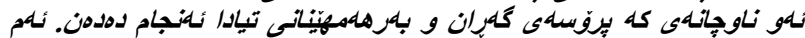

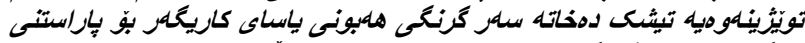

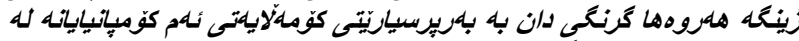

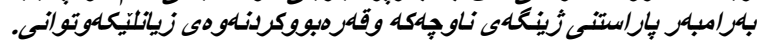
ملخص البجث

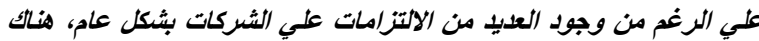

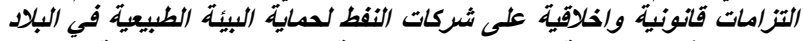

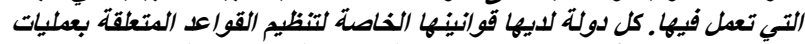
شركات النفط من أجل الحفاظ على البيئة الطبيعية من منطقة عدلها. الامتثال

\begin{abstract}
لهذه المتطلبات فيها مصلحة مشتركة لكل من البلد المضيف والثركتة وهذا

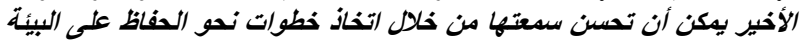

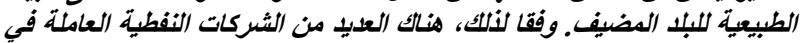

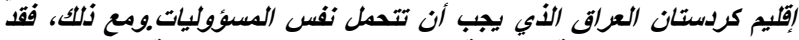

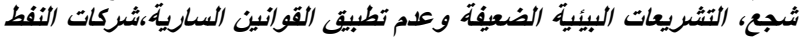

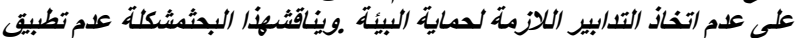

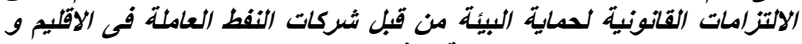

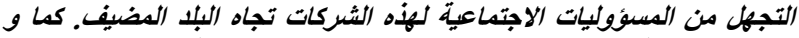

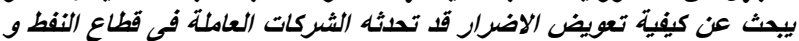

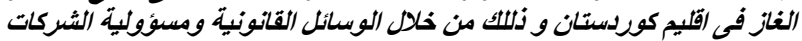

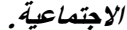

\section{INTRODUCTION}

Many environmental disasters have happened because of human activities which have numerous harmful consequences. Multiple stakeholder groups continuously demand managers to devote resources to corporate social responsibility. Generally, the ethical obligations toward natural environment cover human values toward natural resources and environment protection, particularly when human's involvement has become crucial in reducing pollution after the rapid growth of population and industry. The demands for reforms emerged from customers, suppliers, employees, community groups, stockholders and government. Social responsibility can be introduced as the responsibilities of the foundation toward consumers, workers, stakeholders and the community. It is defined as "a concept whereby companies integrate social and environmental concerns in their business operations and in their interaction with the stakeholders on a voluntary basis." Environment protection used to be considered as a public interest and a government's principal responsibility to assuring environmental management. The main priority of the government was to create and preserve a safe environment. It has utilized many tools to achieve this goal such as regulations, sanctions and even incentives. Thus, public sectors generally bore the 
duty of mitigation of environmental damages in the past decades. However, this attitude has been slightly changed when the role of sectors has also shifted toward the active participation of private sectors. Therefore, nowadays, it is the responsibility of corporations to cover the environmental implications of their operations, facilities, production and eliminating emissions. The ethical obligation of any firm requires actions beyond legal requirements such as abating pollution, recycling, supporting local businesses and adopting progressive human resource management programs. ${ }^{1}$ Furthermore, the concept of corporate social responsibility is considered to be a challenge of any business to behave in accordance to sets of principles such as Human Rights, environmental protection, anticorruption actions and labor standards. ${ }^{2}$ In Kurdistan region, the issue of legal and ethical obligations of oil companies toward the protection of environment has not been implemented properly.

\section{RESEARCH OBJECTIVES}

Environment has been facing many risks in the recent years. There are many international oil companies exploring and producing oil in Kurdistan region. The legal obligations of these companies in preserving natural environment are not in a required level. Thus, alongside legal obligations, it is quite vital to insist on social responsibility of oil companies in this regard. In another word, there is a need from the KRG side to be aware of these responsibilities in return of using land to conduct their operations. There are very few research conducted in this field despite the fact that oil companies are exempted not just from corporate social responsibilities but also from legal obligations toward protecting environment. Therefore, the paper will indicate all legal and ethical obligations of oil companies in preserving environment in Kurdistan region.

\section{PROBLEM OF THE RESEARCH}

The lack of sufficient environmental legislations and inadequate implementation of applicable laws have led oil companies not to comply with the rules concerning environmental protection. This problematic issue has been addressed throughout the paper. The KRG tried to provide many incentives to convince oil companies to operate in the Region which made the position of the government very weak in imposing sufficient conditions

\footnotetext{
${ }^{1}$ AbagailMcwilliams\& Donald Siegel, 'Corporate Social Responsibility: A Theory of a Firm Perspective' Academy of Management Review, 2001, Vol 26, No 1, at 117-118.

2 Maria Curie 'Corporate Social Responsibility toward the Environment-The Involvement of Polish Enterprises in the Implementation of the Idea of CSR' B.OlyszkoKurzyna 2014, at 14 391
}

with regard to protect natural environment. As the result, corporate social responsibility of oil companies working in the region has been neglected.

\section{Research methodology}

An analytical approach has been adopted in conducting the research; the paper relied on all relevant laws and legislations regulating the protection of environment alongside contractual obligations of oil companies. Moreover, relevant books and academic journals have been relied on to conduct the research.

\section{RESEARCH OUTLINES}

The paper has been divided into two chapters. The first chapter will cover the legal obligations of petroleum companies in preserving environment by addressing all environmental legislations in the Iraqi legal system and the KRG in particular, and the obligation of oil companies in paying compensation in case of violating any legal provisions. In the second chapter, corporate social responsibilities of oil companies will be discussed with particular focus on ethical obligations of oil companies toward protecting environment in the Kurdistan region.

\section{CHAPTER ONE}

\section{LEGAL OBLIGATIONS OF OIL COMPANIES TOWARD PRESERVING NATURAL ENVIRONMENT}

Environmental consideration must become part of corporate strategies alongside environmental principles related to raw material extraction that might have disastrous impact on natural environment. Apparently, the obligations of protecting environment can be stemmed from either applicable legislations or the agreements between the parties of the contract, namely oil companies and host governments, in conjunction with international declarations and treaties. In this chapter, the sources of legal obligations and the right to demand compensation for environmental damages would be discussed.

\section{A. Environmental legislations in the $K R G$}

Environment is generally protected under both domestic and international law. Environmental regulations are the standards that have been adopted by states in order to manage natural resources and environmental quality; including areas as water and air pollution, wildlife, forests and agriculture practices. These standards can apply on both public and private sectors. ${ }^{3}$ In Iraq, there are many regulations concerning

${ }^{3}$ Domestic Environmental laws, available at
[https://www.google.iq/?gfe rd=cr\&ei=UQIWVvnDFM6z8weQmoGw


the protection of natural resources ${ }^{1}$, in particular water resources. The increase in industrial activities had led the government to make stricter legislations in order to prevent pollution and catastrophic consequences of operation by large companies. Likewise, in the Kurdistan Region of Iraq, parliament has issued similar laws such as Kurdistan Region Environment Protection and Improvement Law No. 8 of 2008. In all applicable codes that have been mentioned in the footnote there is an emphasis on protecting natural resources. For instance, article 14 of Protection and Improvement of Environment Law no. 27 for the year 2009 in Iraq, determines number of harmful acts and water pollutants. Moreover, article 33 of the same law has given authority to relevant minster to "...Warn any establishment, factory or any authority or environment polluter to remove the affecting factor within ten days from the date a warning notification is served. In case of noncompliance with the minister's order, the minister may suspend the activity or order temporary closure for no longer than thirty days, which may be extended until the violation is removed."

With regard to oil and gas sector, there is not any specific environment legislation regulating the operations of oil companies working in the Kurdistan region. However, the KRG's Oil and Gas Law 2007 has given authority to the Ministry of Natural Resources to make regulation for protection and restoration of the environment. ${ }^{2}$ Furthermore, the law has given an authority to the Minister to "ensure that the petroleum industry is developed in a way that minimizes damage to the natural environment, it is economically sustainable, promotes further investment and contributes to the longterm development of the Region; and is reasonable and consistent with good oil industry practices." ${ }^{3}$ Nevertheless, the issue of legal protection of environment against oil companies has been ignored. Thus, it is necessary to have a specific regulation concerning the protection of natural environment in the Kurdistan region.

The obligations to protect environment has been emphasized in the KRG's Production Sharing Contracted signed with international oil companies. For instance, article 37/first of the KRG's production

DA\&gws $r d=s s \mid \# q=$ protecting+environment+under+domestic+law] accessed on 20 August 2016.

${ }^{1}$ The most prominent legislations are: [Regulations No. 2 for the year 2001: Preservation of Water Resources], [Law no. 27 for the year 2009: Protection and Improvement of Environment], [Law no. 37 for the year 2008: The Ministry of Environment], [Law no. 55 for the year 2002: The Law of Antiquities and Heritage, Forest and Woodlots], Law No. 30 of 2009 and many other bylaws and instructions in different governmental departments.

\footnotetext{
${ }^{2}$ Article 53/sixth of the KRG's Oil and Gas Law No 28 of 2007.
}

${ }^{3}$ Article $7 /$ second, lbid. sharing contracts states that "During the performance of the Petroleum Operations, the contractorshall take necessary measures to ensure that it, the Operator, its Subcontractors and agents attend to the protection of the environment and prevention of pollution, in accordance with standard practice in the international petroleum industry and any applicable Kurdistan Region Law." The rest of the sections in the same article have mentioned the necessary measures to be taken to protect the natural environment. Nonetheless, it is significant to take into consideration the importance of the application of the regulatory framework; meaning that the enforcement measures are much important than having theoretical or abstract status. The World Bank for example, in their report on environmental governance in oil producing developing countries 'surveyed 32' countries) indicates that "in the majority of countries surveyed, a sufficiently appropriate, but largely theoretical, environmental policy and legal framework is in place for managing impacts of the oil and gas industry". 4

According to the opinion of a Member of the KRG Environment Protection and Improvement Law Draft Committee; there are three main problematic issues with Iraq's current environmental legislation and its implementation;

"1. The implementation of current environmental laws is lacking. Although the Iraqi parliament has legislated these laws, there are no effective mechanisms to monitor the implementation of these laws;

2. Current Iraqi environmental legislation is overlapping and requires the oil and gas operators to acquire multiple licenses from various ministries. This tends to cause friction since various government agencies dump their work onto others therefore producing inertia to oil and gas development;

3. Members of the executive bodies overseeing environmental legislation are inexperienced and unqualified for handling such positions since appointments are partisan and political."

The ecological side of oil industry has been recognized in many international events and become a great concern for the international community since the realization of its catastrophic consequences. The United Nations Conference on Environment and Development (UNCED) held in Rio in 1992 is a clear example when various environmental problems put into a general

\footnotetext{
4 World Bank, Environmental Governance in Oil Producing Developing Countries, managed by EleodoroMayorgaAlba,June 2010, at 8-10.

${ }^{5}$ Khalid I. Al.Saleem, 'The Legal Framework for the Sustainable Development of Iraqi Oil and Gas: a Study in Particular Reference to the Kurdistan Region, and with Special Emphasis on the New Delhi Declaration', the PhD thesis, January 2015, at 235.
} 
global context. ' Moreover, the Kyoto Protocol in 1992

is considered to be the effective covenant under the name of United Nations Framework Convention on Climate Change (UNFCCC) which has 192 parties. $^{2}$ The main objective of the protocol is to manage emissions of greenhouse gases. This protocol is considered hard international law which forces state parties to act accordingly. ${ }^{3}$ In addition, soft international law which includes all declarative principles and agreements, influences states more effectively in order to respect specific norms and values; thus, soft international law can be used to push the states toward the protection of environment. Soft law has a similar impact as ethical obligations or social responsibility. It is widely agreed that soft law is more effective than enforceable hard international law. Mauro Barelli has dissented on the ground that soft law sometimes appear to be more valued than binding instruments. ${ }^{4}$ In general, a small number of ratification of a treaty makes it impaired compared with the great response by the state to the declaration. Another point is that soft law allows nonstate actors to participate in negotiation and law-making process unlike treaties which exclude this kind of participation by non-state actors. ${ }^{5}$ To end up, it can be said that to some extent the provisions of protecting environment is on place despite having some loopholes. However, the problematic issue is the disregard of applying these provisions to prevent damage to natural environment as a result of operations by oil companies working in the Kurdistan Region. In the following part, the obligations of oil companies to pay a fair compensation would be discussed within the context of agreements and applicable legislations in the KRG.

\section{B. The obligation of paying fair compensation}

Compensation can be enforced on oil companies as a minimum right to the victims of destroyed nature and polluted environment. National and international environmental law offers a rich source of models of damage assessment, in which the injured party is usually the national or international community as whole rather than private individuals. In effect, the claimant is not former but future generations, whose equitable interests

\footnotetext{
${ }^{1}$ Environmental Management in Oil and Gas Exploration and Production, Joint E\&P Forum and United Nation Environment Program Technical Production, 1997, at 2.

${ }^{2}$ Kyoto Protocol to the United Nations Framework Convention on Climate Change (UNFCCC), available at [http://unfccc.int/kyoto_protocol/items/2830.php] accessed on 27 August 2016.

${ }^{3}$ Ibid.

${ }^{4}$ Mauro Barelli, 'The Role of Soft Law in the International Legal System: the case of the United Nation Declaration on The Rights of Indigenous Peoples ' International and Comparative Law Quarterly, 2009, Vol.58, issue 4, at .963-965.

${ }^{5}$ lbid.

393
}

in a clean and healthy environment need to be protected now; payment of compensation in the present is a mechanism to discourage additional spoliation. ${ }^{6}$ The general principle in environmental regulations is that the pollution costs and damages shall be borne by the creators; including health, property and natural resource damages. ${ }^{7}$ The oil Companies are responsible to compensate for all kinds of damages; for instance, many residents of the Niger Delta have complained of asthma, breathing difficulties and pain, headaches, nausea, and throat irritation as well as chronic bronchitis that can be the subjects of lawsuits against the oil operator as it happened in the Nigerian case of Jonah Gbemre v. Shell, in which the Nigerian federal court held that gas flaring and oil spillage by Shell in the course of their oil exploration and production activities in the applicant's community were violations of the fundamental right to a healthy environment and dignity of human persons. ${ }^{8}$

With regard to the KRG's Oil and Gas law, the law has forced the operator to pay reasonable compensation if in the course of petroleum operation, it "(a) disturbs the rights of the owner of any Asset, or causes any damage thereon; or (b) demonstrably interferes with any other lawful activities." 9 Further, the payable compensation shall not be less than the amount of the loss caused by the operators. ${ }^{10}$ With regard to the amount of payment, the Ministry of Natural Resources shall estimate and decide a fair and reasonable compensation payable by the Authorized Person ${ }^{11}$ under this Article, after having considered representations by interested parties. The Authorized Person may be entitled to arbitration in accordance with any arbitration provisions and the affected Person shall be entitled to rely on the specialized courts in the Region to object to a compensation decision. ${ }^{12}$ Furthermore, in the signed petroleum contracts, there are many types of compensation decided to be paid by the petroleum companies. This compensation can be acquired in return of using the land for exploration and discovery operations when oil companies shall pay the land owner

\footnotetext{
${ }^{6}$ Peter Wetterstein, ed., Harm to the Environment: The Right to Compensation and the Assessment of Damages (Clarendon Press, 1997).

${ }^{7}$ James Boyd, 'Financial Responsibility for Environmental Obligations: An Analysis of Environmental Bonding and Assurance Rules', Research in Law and Economic, 2002, at 1-2.

${ }^{8}$ Damilola S. Olawuyi, 'Legal and Sustainable Development Impacts of Major Oil Spills' The Journal of Sustainable Development, 2012, Vol 9 , issue 1 , at 9 .

${ }^{9}$ Article $29 /$ second (1), supra note 8.

${ }^{10}$ Article $29 /$ second (2), supra note 8 .

${ }^{11}$ Authorized Person: in respect of a Petroleum Contract, a Contractor; or the Person to whom the responsibility has been granted in accordance with the Authorization and Access Authorization (article 1/24 of the KRG's Oil and Gas Law, No 28 of 2007).

${ }^{12}$ Article 29/third, supra note 8.
} 
or the government if the agreement could not be reached with the owner. ${ }^{1}$ This is the general civil liability of all companies if they utilize a land belonged to a private party. On the other hand, despite the fact that there is no clear obligations of oil companies to pay for any damages caused to the environment as the result of oil operations, the KRG has dedicated some funds to support the protection of environment. For instance, article 57 of the KRG's Oil and Gas Law states that "A percentage from the Petroleum Revenues shall be used to protect the rights of the future generations, to fund strategic projects in the Region, to protect the environment, to support the families of the martyrs, and to support the necessary needs of the citizens of Kurdistan to achieve fairness amongst its religious and ethnic composition and this shall be regulated by law". ${ }^{2}$ Moreover, according to the production sharing contracts terms, oil companies must adhere to the payment specified under the provisions of the Oil and Gas Law for the environmental support. ${ }^{3}$ As the result, the Oil companies' obligation to dedicate some funds can only be found in the signed production sharing contracts under the environment fund by devoting a specific amount of money each contract year during both exploration and production periods. ${ }^{4}$ In the next chapter, the social responsibilities of oil companies to protect environment will be discussed.

\section{CHAPTER TWO}

\section{ETHICAL OBLIGATIONS OF OIL COMPANIES TO PROTECT ENVIRONMENT}

It has been recognized that business cannot be conducted in a social vacuum; there are many social norms and expectations that must be taken into account by corporations. Oil and gas companies conduct their activities within a more complex set of social norms alongside legal requirements. In this chapter, corporate social responsibilities of oil companies will be discussed.

\section{A. The concept of Corporate Social Responsibility}

Corporate social responsibility is an obligation to consider not just an interest of enterprise's shareholders but rather the benefit of all stakeholders that influenced by the activities of the project. The early basis of social responsibility can be returned back to Henry Ford's announcement in 1917 regarding the aim of the

\footnotetext{
${ }^{1}$ Article 17.2 of the KRG's model of production sharing contracts.

${ }^{2}$ Article $57 /$ First, supra note 8.

${ }^{3}$ Article $37 /$ First(10), supra note 8 .

${ }^{4}$ Article 23.8, supra note 24 .
}

company by saying that "To do as much as possible for everybody concerned, to make money and use it, give employment, and send out the car where the people can use it ....and incidentally to make money". Ford was one of those companies that initiated social responsibility from a business practice perspective. ${ }^{5}$ In the management area, since 1950s many terms have been used to describe the ethical obligation of a company such as corporate social responses, corporate social responsiveness, corporate social performance, corporate philanthropy and corporate citizenship. ${ }^{6}$

In addition, Davis argued that Social responsibility should be seen in a managerial context he asserted that "Some socially responsible business decisions can be justified by a long, complicated process of reasoning as having a good chance of bringing long-run economic gain to the firm, thus paying it back for its socially responsible outlook." "7 Hart and Simmons described the nature of the obligation in Social responsibility as a moral requirement which is generated by voluntary acts and a correlative right is also generated in the transactions. $^{8}$ Thus, it can be said that social responsibility is a set of ethical rules and standards considered to be binding morally.

\section{B. Corporate social responsibilities and environment protection}

Protecting natural environment covers many areas such as national forest, clear cutting, biodiversity, preservation of endangered species, timber salvage and sustainability. In this context, the issue goes around ethical obligation rather than legal obligation; environmental ethics deals with human behavior and conduct toward natural environment as there is a direct interaction between human and nature in general. ${ }^{9}$ Ethics can be described as "study or discipline which concern itself with judgments of approval and disapproval, judgments as to the rightness or wrongness, goodness or sadness, virtue or vice, desirability or wisdom of actions, disposition, ends, objects or states of affairs". ${ }^{10}$ Furthermore, environmental ethics can be

\footnotetext{
${ }^{5}$ Shuo Wang, 'Chinese Strategic Decision Making on Corporate Social Responsibility' (Springer 2015) at 7.

${ }^{6}$ Dirk Matten and Andrew Crane Corporate Citizenship: Toward an Extended Theoretical Conceptualization the Academy of Management Review, 2005, Vol. 30, No. 1, at 166-169.

${ }^{7}$ Archie B. Carroll, "Corporate Social Responsibility: Evolution of a Definitional Construct", Business \& Society, 1999, Vol.38, No.3, at 271.

${ }^{8}$ Robert A. Phillips and Joel Reichart, "The Environment as a Stakeholder? a Fairness Based Approach", Journal of Business Ethic, 2000 , at $185-186$

${ }^{9}$ Ibid, at 180-181.

${ }^{10}$ Robert Manning and others, "Values, Ethics and Attitudes toward National Forest Management: An Empirical Study", Society and Natural Resources, 1999, at 422-423.
} 
defined as "the diversity of ideas that derive human relationships with the natural environment, examples include stewardship of nature as a religious duty and intrinsic right of nature." In business companies, corporate social responsibility covers various areas such as: public environment, market environment and all other areas related to investors and environmental protection; raising awareness regarding all these issues is an essential part in corporate social responsibility. To sum up, apart from legal framework enforced by valid regulations on any firm, any corporation should do the following as part of the Corporate Social Responsibility:

- Protect, respect and restore natural ecosystem.

- Reducing the consumption of energy and raw materials.

- Negative environmental effects shall be identified by any firm.

- Using up to date technologies to reduce harm to the environment.

- Ecological behavior shall be promoted inside a company in order to save energy and water in the departments of the corporation. ${ }^{2}$

Thus, it can be said that corporate social responsibility becomes an essential part of any company's value and must be taken into consideration when it comes to a successful management; without this, company's reputation might get damaged in the public.

The social responsibility norms will guide any firm to how such a company deals with natural environment or any other natural resources. Furthermore, many scholars have discovered some areas of Corporate Social Responsibility and particularly the environmental aspects. Alexander Dahlsrud indicates the vagueness in defining the term of Corporate Social Responsibility by saying that there is still some confusion as to how it should be defined. He argues that "the confusion is not so much about how Corporate Social Responsibility is defined, as about how it is socially constructed in a specific context." ${ }^{3}$ Sabina has made a research on the competition between the cost of perusing Corporate Social Responsibility goals and profit maximization. The research argued that the benefits of utilizing social responsibilities might have significant advantages for both environment and shareholders, particularly if it is conducted voluntarily. ${ }^{4}$ Dirk and Jeremy have classified

\footnotetext{
${ }^{1}$ Ibid, at 422-426.

${ }^{2}$ Maria Curie 'Corporate Social Responsibility toward the Environment-The Involvement of Polish Enterprises in the Implementation of the Idea of CSR' B.OlyszkoKurzyna 2014, at 125126.

${ }^{3}$ Alexander Dahlsrud, "How Corporate Social Responsibility is defined: an Analysis of 37 Definitions", Corporate Social Responsibility and Environment Management, 2006, at 1-2. Sabina Medarevic, "Environmental Corporate Social Responsibility and the Carbon Economy: A Case for CSR, the Triple Bottom Line and Obliquity" Corporate Governance E journal, 2012, at 23.

Corporate Social Responsibility to explicit and implicit types by differentiating American and European perspective toward the concept. ${ }^{5}$ Abagail and Donald Siegel in their research of " Corporate social responsibility and Financial Performance: Correlation or Misspecification" have explained the impact of social responsibility on financial performance and indicated that due to the lack of an empirical analysis different results have been come out by researchers on this correlation. They state that "Researchers have reported a positive, negative, and neutral impact of corporate social responsibility on financial performance. This inconsistency may be due to flawed empirical analysis." ${ }^{\circ 6}$ Elisabet and Domenic have done a paper on the Corporate Social Responsibility theories and approaches and classified them into four theories, namely instrumental theories, political theories, integrative theories and ethical theories. The finding throughout their research suggested the need to introduce a new theory on the business and society relationships as a result of mixing these four dimensions. $^{7}$ Nader Ghotbi has emphasized the significance of preserving natural environment to serve the future generations by saying that " the mainstream ethical philosophies have found it difficult to assign an intrinsic value to the environment itself, and most environmental ethics is based on "enlightened" anthropocentrism which values environmental protection for the sake of other humans including the future generations" ${ }^{\prime 8}$ Carroll identifies four stages of the development of corporate social responsibility including legal, economic, ethical and philanthropic obligations. He further argues that "these four categories are not mutually exclusive, nor are they intended to portray a continuum with economic concerns on one end and social concerns on the other". 9 From the marketing perspective, scholars have discussed between social responsibility and marketing management which is mainly focuses on one figure of stakeholder, namely consumers. However, there might be many other initiatives such as: employee satisfaction and environment management. Maignan and Ferrell believe that there are two motivations behind organizational corporate social responsibility: the instrumental approach is the first approach by which companies

\footnotetext{
${ }^{5}$ Dirk Matten and Jeremy Moon, " A Conceptual framework for understanding CSR in Europe", International Centre for Corporate Social Responsibility, 2004, No.29, at 41-45.

${ }^{6}$ Supra note 3, at 120-125.

${ }^{7}$ ElisabetGarriga and DomenecMele, "Corporate Social Responsibility Theories: Mapping the Territory" Journal of Business Ethic, 2004, at 51-52.

${ }^{8}$ Nader Ghotbi, "Intrinsic Value of the Natural Environment: an Ethical Roadmap to Protect the Environment" Philosophy Study, 2014, Vol. 4, No. 4, at 315-316.

'LiangrongZu, Corporate Social Responsibility, Corporate Restricting and Firm's Performance (Springer 2009), at 8.
} 
mainly rely on the support of their stakeholders and to consider their claims and needs. The second motivation is moral as Preston and Donaldson have correctly described "all persons or groups with legitimate interests participating in an enterprise do so to obtain benefits and ..... there is no prima facie priority of one set of interests or benefits over another". ${ }^{1}$ In the following section, ethical theories applicable on environment will be discussed.

\section{Applying ethical theories to the environment}

The perspective of three ethical theories will be illustrated here:

\section{Utilitarianism}

The main stream of utilitarianism theory is the great good for great number of people, based on this viewpoint, as long as destroying environment bring harm to the great number of individual and species in a long-term period with a short term advantage to a small group of people, utilitarian weight up long term harm against gains for the short term in exploiting natural resources. Qualitative Utilitarianism considers whether the course of action causes the maximization of higher pleasure for the current and future generations or not. Further, modern utilitarian use the cost benefit analysis approach; which is known as David Pearce's Blue print for a green economy which consider the cost and benefit for any action. For instance, implementing a project that need to deforest a wide area might bring money for the owner or a small group of people meanwhile it might have a harmful effect in the future. ${ }^{2}$ However, Preference utilitarianism argues that 'the moral course of action is the maximization of preference satisfaction for the current generation. Assuming that neglecting the environment has no major effect on the current generation, then the case for preserving the environment is weak.' Peter Singer gives an example of establishing hydroelectric dam that might result in creating job opportunities, providing energy and economic growth in the area. At the same time, building such project will spoil the beauty of the landscape and destroy the habitat of many endangered species. ${ }^{3}$ For the qualitative utilitarian will prefer the long term benefit for the future generation, Whereas the preference utilitarian outweigh the cheap electricity supply over the landscape and natural resource destruction.

\section{Kant theory}

Although many philosophers have rejected the Kant's account of duties about non-human nature, claiming that

\footnotetext{
1 Alasdair Cochrane, "Environmental Ethics" available at[http://www.iep.utm.edu/envi-eth/] accessed on 23 Sept 2016.

${ }^{2}$ Peter Singer, "Environmental and Business Ethics", OCR A level religious studies specification, $15 \mathrm{C}$, at 234 .

${ }^{3}$ Ibid, at 235. 396
}

it has not an adequate moral concern for natural resources and all other non-human entities around us. However, this traditional interpretation of Kant's point of view is mistaken, as Toby has indicated "Kant's account of duties regarding nature grounds much stronger limitations on how humans may treat nonhuman animals and flora, since such duties are rooted in the imperfect duty to increase one's own moral perfection." "The main basis of the Kant's theory is the ultimate value of rational nature; Kant denies that domestic animals can be treated as tools. He believes that human has moral duty toward natural world and it must not be destroyed.

Virtue ethics

In the previous theories, the emphasis was on duty and consequences which are also called anthropocentric theories. Environment Virtue Ethic is a new approach which tries to explain the relationships between human and natural world more objectively. Its main focus is on how we are to live in the natural world instead of duty and consequences. It further sees 'a virtuous life in nature as a necessary condition of human flourishing. Extremes of behavior are unhelpful both for society and the environment. ${ }^{5}$ Thus, it can be said that all three theories are trying to illustrate the relationship between human beings and environment. In the subsequent section, the corporate social responsibility of oil companies will be examined in the context of their operations in Kurdistan Region.

\section{The Corporate Social Responsibilities of Oil companies operating in the $K R G$}

The concept of corporate social responsibility is rather a new topic for Iraq and Kurdistan region. Companies do not care much about the social responsibility of their entity toward the population of the country where they operate. The Kurdistan Regional Government has given plenty incentives to foreign investors in a way that negatively impacted on the position of the host government. Oil companies are trying to fulfill the minimum level of their legal obligations. There are few instances in the applicable legislations of the KRG where social responsibilities of oil companies can be found.

Article 24 of the KRG's Oil and Gas law has set a criteria to be met in signing a contract with the opposite party by stating that "a person must demonstrate....a record of compliance with principles of good corporate citizenship, and a commitment to the Ten Principles of the Global Compact, launched by the United Nations on

\footnotetext{
${ }^{4}$ Toby Svoboda, "Duties regarding Nature: A Kantian Approach to Environmental Ethics" Kant Yearbook ,2012,4(1), at 143.

${ }^{5}$ Supra note 44 , at 235.
} 
26 July 2000." Out of these ten principles, three principles, 7,8 and 9 , have been dedicated to environmental protection. They are stating that businesses should support a precautionary approach to environmental challenges; undertake initiatives to promote greater environmental responsibility; and encourage the development and diffusion of environmentally friendly technologies. ${ }^{2}$ Moreover, "good corporate citizenship" stated in the law is referring to corporate social responsibilities of the oil operator in the region. ${ }^{3}$ This has been emphasized in the preamble of the production sharing contract model adopted by the KRG “...having a record of compliance with the principles of good corporate citizenship..."4 Apart from these two areas where such responsibility stated, there are not other detailed statements regarding social responsibilities of oil corporations. In fact, these statements are insufficient as they are conditions for signing a contract and as long as the contracts signed, there is no any evidence that such conditions are implemented.

In contrast, the KRG's PSCs has given an opportunity to the operating oil companies after signing the contract to "freely use sand, water, electricity and any other natural resources located inside or outside the Contract Area for the Petroleum Operations;". ${ }^{5}$ This will give an absolute power to the oil companies in exploiting all other natural resources for the sake of their operation in different locations. Thus, and at their own discretion, companies allocate voluntary funds towards Corporate Social Responsibility programs to help them gain, secure or retain social licenses to operate. For instance, WesternZargos who operated in the KRG for quite a long time, has stated that: "WesternZagros is committed to conducting our business ethically, legally, and in a manner that is fiscally, environmentally and socially responsible. As WesternZagros continues to evolve as an organization beyond an exploration company, we will continue to implement changes to reflect leading corporate responsibility practices." ${ }^{\prime 6}$ Thus, it can be realized that the issue of oil companies' social responsibilities has not been granted proper attention by the Kurdistan Regional Government as they were not successful in creating a system that encourages oil companies to develop their social responsibility programs to serve operation areas and protect the environment.

\footnotetext{
${ }^{1}$ Article 24 /third (2), supra note 8 .

2 The ten principles of the UN Global Impact, available at [https://www.unglobalcompact.org/what-is-gc/mission/principles] accessed on 1 October 2016.

3 Derived Investopedia,

[http://www.investopedia.com/terms/c/corporatecitizenship.asp] accessed on 29 Sept 2016.

${ }^{4}$ The preamble of the KRG's model of production sharing contracts.

${ }^{5}$ Article 2.8 , supra note 24 .

${ }^{6}$ WesternZagroz web page, [http://www.westernzagros.com/csr/] accessed on 2 October2016.
}

\section{CONCLUSION}

This paper has focused on many issues related to the legal and ethical responsibilities toward natural environment. Alongside legal obligations enforced by applicable laws and regulations in every country, there are other ethical obligations for oil companies to behave in a manner not to focus only on the maximization of profit but also to protect the reputation of the firm before stakeholders. Legal obligations stem from legal statutes and provisions in agreements between host country and international oil companies. Inappropriateness of environmental legislation and the insufficient application of the existing laws in Kurdistan region have led to many loopholes that have been exploited by oil companies to ignore environmental concerns. Consequently, there is a need to concentrate on other means such as corporate social responsibilities to protect natural environment. There are many definitions by scholars to the concept of corporate social responsibility; it can be introduced as the integration of environmental and social concerns into their business. In each country, there are many rules to enforce some standards on companies in order to keep the environment and natural resources safe. However, companies are always trying to breach rules for their economic benefit. The most recent example was the Volkswagen emission test scandal. ${ }^{7}$ By looking at the KRG's legislations and agreements, no statement can be found on corporate social responsibilities of oil companies operate in the region except of some indirect hints to the concept such as Principles of the Global Compact and Good Corporate Citizenship. Therefore, as the Association of German Chambers of Industry and Commerce stated repeatedly that "Corporate Social Responsibility is a widely spread concern on the management level and that the voluntary approach would lead to best results." Companies should adopt some voluntary action to show their concern for environment such as reducing the consumption of raw materials and utilize all kinds of technology to keep the atmosphere clean. There are three theories explaining the ethical obligation toward natural environment which are Utilitarian, Kantian and Virtue ethics approaches; all three insisting on preserving natural environment but from different perspective.

\section{RECOMMENDATIONS}

- The KRG's Oil and Gas Law no 28 of 2007 should be amended by adding articles to regulate the protection of natural environment.

- The Kurdistan Regional Government shall work on

\footnotetext{
7 The Volkswagen emissions scandal explained, available at [http://www.theguardian.com/business/nginteractive/2015/sep/23/volkswagen-emissions-scandal-explaineddiesel-cars] accessed on 3 October 2016.
} 
JUHD / Vol. 2, No. 4, December 2016: pp 390-399

e-ISSN: 2411-7757, p-ISSN 2411-7765

the issuance of more effective legislations to prevent environment pollution as the result of oil companies' operations.

- The KRG shall enforce oil companies, by law, to dedicate a percentage of profit oil for raising awareness with regard to preserving natural environment.

- Oil companies shall not be exempted from taxes unless they provide funds to protect environment, especially in operation areas.

- Oil companies shall be obligated to pay fair compensation in case of any destruction to the environment.

\section{REFERENCES}

Legislations \& agreements:

[1] The KRG's Oil and Gas Law No.28 of 2007.

[2] Regulations no. 2 for the year 2001

[3] Preservation of Water Resources, Law no. 27 for the year 2009.

[4] Protection and Improvement of Environment, Law no. 37 for the year 2008.

[5] The Ministry of Environment, Law no. 55 for the year 2002.

[6] The Law of Antiquities and Heritage, Forest and Woodlots Law No. 30 of 2009.

[7] Kyoto Protocol

[8] The KRG's model of production sharing contracts.

Journal articles

[9] AbagailMcwilliams\& Donald Siegel, 'Corporate Social Responsibility: A Theory of a Firm Perspective' Academy of Management Review, 2001, Vol 26, No 1.

[10] Alexander Dahlsrud, "How Corporate Social Responsibility is defined: an Analysis of 37 Definitions", Corporate Social Responsibility and Environment Management, 2006.

[11] Archie B. Carroll, "Corporate Social Responsibility: Evolution of a Definitional Construct”, Business \& Society, 1999, Vol.38, No.3.

[12] Damilola S. Olawuyi, 'Legal and Sustainable Development Impacts of Major Oil Spills' The Journal of Sustainable Development, 2012, Vol 9, issue 1.

[13] David M. Ong, "The Impact of Environmental Law on Corporate Governance: International and Comparative Perspectives", EJIL, 2001, Vol 12, No 4, at 685.

[14] Dirk Matten and Jeremy Moon, "A Conceptual framework for understanding CSR in Europe", International Centre for Corporate Social Responsibility, 2004, No.29.

[15] Dirk Matten and Andrew Crane Corporate Citizenship: Toward an Extended Theoretical Conceptualization the Academy of Management Review, 2005, Vol. 30, No. 1.

[16] ElisabetGarriga and DomenecMele, "Corporate Social Responsibility Theories: Mapping the Territory" Journal of Business Ethic, 2012.

[17] James Boyd, 'Financial Responsibility for Environmental Obligations: An Analysis of Environmental Bonding and Assurance Rules', Research in Law and Economic, 2002.

[18] Khalid I. Al.Saleem, the PhD thesis titled 'The Legal Framework for the Sustainable Development of Iraqi Oil and Gas: a Study in Particular Reference to the Kurdistan Region, and with Special Emphasis on the New Delhi Declaration', January 2015.

[19] Maria Curie 'Corporate Social Responsibility toward the Environment-The Involvement of Polish Enterprises in the Implementation of the Idea of CSR' B.OlyszkoKurzyna 2014.

[20] Mauro Barelli, 'The Role of Soft Law in the International Legal System: the case of the United Nation Declaration on The Rights of Indigenous Peoples ' International and Comparative Law Quarterly, 2009, Vol.58, issue 4.

[21] Nader Ghotbi, "Intrinsic Value of the Natural Environment: an Ethical Roadmap to Protect the Environment" Philosophy Study, 2014, Vol. 4, No. 4.

[22] Peter Singer, "Environmental and Business Ethics", OCR A level religious studies specification, $15 C$.

[23] Robert A. Phillips and Joel Reichart, "The Environment as a Stakeholder? a Fairness Based Approach", Journal of Business Ethic, 2000.

[24] Robert Manning and others, "Values, Ethics and Attitudes toward National Forest Management: An Empirical Study", Society and Natural Resources, 1999.

[25] Sabina Medarevic, "Environmental Corporate Social Responsibility and the Carbon Economy: A Case for CSR, the Triple Bottom Line and Obliquity" Corporate Governance E journal, 2012.

[26] Shuo Wang, 'Chinese Strategic Decision Making on CSR' (Springer 2015).

[27] Toby Svoboda, "Duties regarding Nature: A Kantian Approach to Environmental Ethics" Kant Yearbook, 2012, 4(1).

Books

[28] LiangrongZu, Corporate Social Responsibility, Corporate Restructing and Firm's Performance (Springer 2009).

[29] Peter Wetterstein, ed., Harm to the Environment: The Right to Compensation and the Assessment of Damages (Clarendon Press, 1997).

[30] YuvrajPatil, 'Corporate Social Responsibility toward Environmental Management', (Symbiosis Law School, 2014).

Webs

[31] Domestic Environmental law, available at [https://www.google.iq/?gfe_rd =cr\&ei=UQlWVvnDFM6z8weQ moGwDA\&gws_rd $=s s l \# q=$ protecting + environment + under $+d o$ mestic+law].

[32] Alasdair Cochrane, "Environmental Ethics" available at [http://www.iep.utm.edu/envi-eth/] accessed on 23 Sept 2016.

[33] The ten principles of the UN Global Impact, available at [https://www.unglobalcompact.org/what-isgc/mission/principles].

[34] Investopedia [http://www.investopedia.com/terms/c/corporatecitizenship.asp]

[35] WesternZagroz web page, [http://www.westernzagros.com/csr/]

[36] The Volkswagen emissions scandal explained, available at [http://www.theguardian.com/business/nginteractive/2015/sep/23/volkswagen-emissions-scandalexplained-diesel-cars]

[37] The Berlin International Economics Congress 2012, March 7th10th, 2012, "The Impact of Corporate Social Responsibility on Business Performance - Can it be Measured, and if so, How?, available

[https://www.google.iq/?gfe_rd $=$ cr\&ei=ptxVVtXXBMGo8we4m $K b w C A \& g w s_{-} r d=s s l \# q=$ the + impact + of + corporate + social + res ponsibility].

Miscellaneous

[38] PiotrMazurkiewicz, Corporate Environmental Responsibility, World Bank, 2004.

[39] World Bank, Environmental Governance in Oil Producing Developing Countries, managed by EleodoroMayorgaAlba,June 2010.

[40] Environmental management in Oil and Gas Exploration and Production, Joint E\&P Forum and UNEP Technical Production, 1997. 